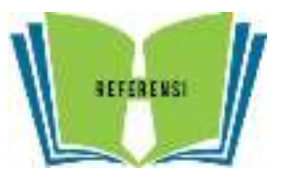

\title{
PENGARUH LEVERAGE TERHADAP INCOME SMOOTHING DAN STOCK RETURN \\ (Studi Pada Perusahaan Jasa Sektor Perbankan Yang Terdaftar di BEI Periode (2010-2015)
}

\section{Tia Maimanah}

Magister Program of Management at Muhammadiyah University of Malang tia.maimanah@gmail.com

\begin{abstract}
This research is aimed at examining the influence of leverage toward the income smoothing and stock return at Banking Service Industries listed on IDX during 2010 until 2015. The population of this research is all banking service industries listed on IDX. Samples are taken by using purposive sampling in which only several samples meeting the criteria which will be taken as samples. This research is considered as explanatory research which explains the result based on specific theories so that it will result various empirical generalisation. Data of this research are analysed by using PLS (Partial Least Square). The result of this study shows that operating leverage significantly influence stock return and financial leverage significantly influence income smoothing. However, operating leverage does not significantly influence income smoothing and financial leverage does not significantly influence stock return. In sum, operating leverage and financial leverage do not influence stock return through income smoothing.
\end{abstract}

Keywords: operating leverage, financial leverage, income smoothing, and stock return.

\begin{abstract}
Abstrak
Penelitian ini bertujuan untuk menguji pengaruh leverage terhadap income smoothing dan stock return pada perusahaan jasa sektor perbankan yang terdaftar di BEI selama periode 2010 sampai dengan 2015. Populasi dalam penelitian ini adalah semua perusahaan jasa sektor perbankan yang terdaftar di BEI. Sampel penelitian ini menggunakan metode purposive sampling sehingga hanya yang memenuhi kriteria tertentu yang akan dijadikan sampel. Jenis penelitian ini tergolong dalam explanatory research yang menerangkan suatu penelitian berdasarkan teori-teori tertentu sehingga terkumpul berbagai generilasisi empiris. Analisa data dalam penelitian ini menggunakan PLS (partial least square). Hasil penelitian ini menunjukkan bahwa operatingleverage berpengaruh secara singifikan terhadap stock return dan financial leverage berpegaruh secara signifikan terhadap income smoothing. Tetapi operting leverage tidak berpengaruh secara siginifikan terhadap inocme smoothing danfinancial leverage tidak berpengaruh secara siginifikan terhadap stock return. Serta operting leverage dan financial leverage tidak berpengaruh terhadap stock retrun melalui income smoothing.
\end{abstract}

Kata kunci : operating leverage, financial leverage, income smoothing dan stock return 


\section{PENDAHULUAN}

Laporan keuangan merupakan salah satu indikator dalam menilai kinerja suatu perusahaan. Dengan adanya laporan keuangan investor dapat menentukan keputusan dalam investasi mereka. Adanya kecenderungan perhatian dari investor yang hanya tertuju pada informasi laba, memaksa manajer meningkatkan citra perusahaan dengan melakukan dysfunctional behavior (perilaku tidak semestinya) melalui income smoothing (Budiasih, 2009).

Di samping itu, laba akan dilaporkan dalam posisi yang stabil yang memberikan rasa lebih percaya diri bagi pemilik perusahaan. Income smoothing juga bertujuan untuk meningkatkan kepuasaan pemegang saham melalui tingkat pertumbuhan dan stabilitas laba yang dilaporkan, namun masih dalam batas aturan akuntansi yang berlaku. Yang dimaksud batas aturan akuntansi yang berlaku disini adalah mengenai konsep accrual basis, dimana basis akrual adalah suatu basis akuntansi di mana transaksi ekonomi atau peristiwa akuntansi diakui, dicatat, dan disajikan dalam laporan keuangan berdasarkan pengaruh transaksi pada saat terjadinya transaksi tersebut, tanpa memperhatikan waktu kas diterima atau dibayarkan (KKRI, 2014).

Tujuan para investor atau pemegang saham berinvestasi pastinya untuk mendapatkan keuntungan. Selain dividen, investor juga mengharapkan pengembalian (return) saham. Maka sebelum berinvestasi, para investor melakukan analisis keuangan untuk memprediksi harga saham di masa yang akan datang agar nantinya memperoleh tingkat imbal hasil (return) dan keuntungan sesuai dengan yang diharapkan. Imbal hasil (return) merupakan hasil yang diperoleh melalui kegiatan berinvestasi yang dapat berupa imbal hasil (return) yang sudah terjadi (realisasisan) atau imbal hasil (return) ekspektasian yang belum terjadi namun diharapkan akan terjadi di masa mendatang (Jogiyanto, 2010:205).

Penilaian harga saham dapat dilakukan melalui analisis fundamental dengan menggunakan rasio-rasio keuangan seperti rasio proftabilitas, likuiditas, danleverage. Para peneliti biasanya menggunakan teknik yang berbeda-beda dalam menentukan pengembalian (return) saham dan masih minim yang merefleksikan hubungan profitabilitas, likuiditas, danleverage terhadap pengembalian (return) saham (Okky at all, 2015).

Banyak penelitian yang meneliti tentang income smoothing, Christiana (2012) menyatakan bahwa ukuran perusahaan (Firm Size), Profitability, Financial Leverage dan Dividend Payout Ratio tidak berpengaruh terhadap income smoothing. Cecilia (2012) menyatakan bahwa ukuran perusahaan dan leverage operasi tidak berpengaruh terhadap praktik income smoothing, sedangkan profitabilitas berpengaruh terhadap income smoothing. Widana (2013) menyatakan bahwa ukuran perusahaan, dividend payout ratio, serta financial leverage tidak berpengaruh terhadap tindakan income smoothing, sedangkan profitabilitas dan net profit margin berpengaruh terhadap tindakan income smoothing. Xu Fengju (2013) menyatakan bahwa ada hubungan antara financial leverage dan 


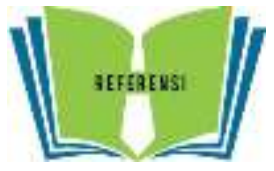

profitabilitas dengan income smoothing.

Berdasarkan uraian diatas maka tujuan penelitian ini adalah untuk mengetahui pengaruh leverage terhadap income smoothing dan stock return. Adapun masalah yang diangkat dalam penelitian ini adalah : (1) Apakah leverage berpengaruh terhadap income smoothing pada Perusahaan Jasa Sektor Perbankan yang terdaftar di BEI periode 20102015? ; (2) Apakah leverage berpengaruh terhadap stock return pada Perusahaan Jasa Sektor Perbankan yang terdaftar di BEI periode 2010-2015? ; (3) Apakah income smoothing berpengaruh terhadap stock return pada Perusahaan Jasa Sektor Perbankan yang terdaftar di BEI periode 20102015?; (4) Apakah leverage berpengaruh terhadap stock return melalui income smoothing pada Perusahaan Jasa Sektor Perbankan yang terdaftar di BEI periode 20102015?

\section{KAJIAN TEORI DAN HIPOTESIS Income Smoothing}

Income smoothing (perataan laba) merupakan salah satu pola dari manajemen laba yakni termasuk dalam teori keagenan. Teori keagenan merupakan terori yang menyatakan bahwa manajemen laba dipengaruhi oleh konflik kepentingan antara manajemen (agent) dan pemilik (principal) yang timbul karena keinginan untuk memaksimalkan kemakmuran masingmasing. (Belkaoui, 2007b:187).

Income smoothing adalah teknik pengurangan fluktuasi laba dengan memindahkan pendapatan dari tahuntahun yang tinggi pendapatannya ke periode-periode yang kurang menguntukan (Belkaoui, 2007a:73). Sedangkan Funddenberg dan Tirole dalam mendefiniskan income smoothing sebagai usaha yang disengaja untuk meratakan atau memfluktuasikan tingkat laba sehinga pada saat sekarang dipandang normal bagi suatu perusahaan. Dalam hal ini, income smoothing menunjukan suatu usaha manajemen perusahaan untuk mengurangi variasi abnormal laba dalam batas-batas yang diijinkan dalam praktik akuntansi dan prinsip manajemen yang wajar.

Status income smoothing suatu perusahaan yang diklasifikasi dengan model Eckel. Eckel menggunakan nilai absolut coefficient variation (CV). Perusahaan dapat diklasifikasikan ke dalam kelompok perata laba apabila mempunyai nilai absolut indeks Eckel kurang dari satu. Indeks Eckel dapat dihitung dengan rumus:

Indeks Income smoothing (IPL) $=\frac{C V \Delta_{I}}{{ }_{C V} \Delta S}$

CV : Koefisien variasi dari variabel (expected value), yaitu standar deviasi dari perubahan laba dan perubahan penjualan dibagi dengan nilai yang diharapkan dari perubahan laba (I) dan perubahan penjualan $(S)$.

$\Delta S$ : perubahan penjualan yang terjadi dalam satu periode.

$\Delta \mathrm{I}$ : perubahan laba yang terjadi dalam satu periode.

\section{Stock Return}

Stock return (pengembalian saham) merupakan hasil yang diperoleh dari suatu investasi dari dana yang sudah diinvestasikan yang dapat dinikmati oleh para investor. Para investor harus menyadari bahwa selain akan memperoleh keuntungan tidak menutup kemungkinan mereka akan mengalami kerugian. Keuntungan atau kerugian yang dialami oleh para investor sangat dipengaruhi oleh kemampuannya dalam menganalisis keadaan harga saham. 


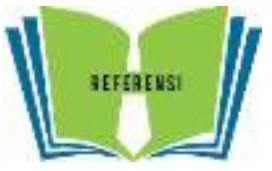

Stock return dapat berupa pengembalian saham realisasi yaitu stock return yang telah terjadi, dihitung berdasarkan data historis dan digunakan untuk mengukur kinerja perusahaan (Jogiyanto 2007: 109).

Rumus menghitung stock return menurut (Jogiyanto 2000 : 87) dapat dirumuskan sebagai berikut:

$$
\mathrm{R}_{\mathrm{t}}=\frac{\mathrm{P}_{\mathrm{t}}-\left(\mathrm{P}_{\mathrm{t}-1}\right)+\mathrm{D}_{\mathrm{t}}}{\mathrm{P}_{\mathrm{t}-1}}
$$

Dimana :

$R t=$ Stock return

$P t=$ Harga saham sekarang

$P t-1=$ Harga saham periode lalu

$D t=$ Dividen yang dibayarkan pada periode sekarang

\section{Leverage}

Arti leverage secara harafiah menurut Hanafi (2004) adalah penungkit. Leverage adalah penggunaan aset dan sumber dana oleh perusahaan yang memiliki biaya tetap (beban tetap) dengan maksud agar meningkatkan keuntungan potensial pemegang saham (Sartono, 2008). Leverage merupakan kemampuan perusahaan dalam menggunakan aktiva dan atau dana yang mempunyai beban tetap dalam rangka mewujudkan tujuan perusahaan untuk memaksimalkan kekayaan pemilik perusahaan.

\section{Operating Leverage (Leverage Operasi)}

Operating leverage adalah seberapa besar perusahaan menggunakan beban tetap operasional (Hanafi, 2004). Menurut Syamsudin (2001), operating leverage adalah kemampuan perusahaan di dalam menggunakan fixed operating cost untuk memperbesar pengaruh dari perubahan volume penjualan terhadap earning before interest and taxes (EBIT).

Dalam Martono (2003) tingkat operating leverage atau disebutdegree of operating leverage (DOL) adalah presentasi perubahan dalam laba operasi (EBIT) yang disebabkan perubahan satu persen dalam output (penjualan), maka degree of operating leverage (DOL) dapat dihitung dengan model berikut:

$$
D O L=\frac{\% \text { Perubahan EBIT }}{\% \text { Perubahan Sales }}
$$

Dimana:

DOL : degree of operating leverage EBIT : Laba sebelum bunga dan pajak Sales : Penjualan

\section{Financial Leverage (Leverage Keuangan)}

Financial leverage menurut Syamsudin (2002) adalah suatu ukuran yang menunjukkan sejauh mana hutang (modal) dan saham prefern digunakan dalam struktur modal perusahaan. Leverage perusahaan akan mempengaruhi laba per lembar saham, tingkat risiko dan nilai harga saham.

Tingkat financial leverage atau degree of financial leverage (DFL) merupakan persentase perubahan laba per lembar saham (EPS) yang diakibatkan adanya perubahan dalam laba operasi (EBIT). Berikut model dari degree of financial leverage (DFL):

$$
D F L=\frac{\text { \%Perubahan EPS }}{\text { \%Perubahan EBIT }}
$$

Dimana:

DFL : degree of financial leverage

EBIT : Laba operasi sebelum bunga dan pajak

EPS : Laba per lembar saham Berdasarkan landasan teori maka sebagai acuan untuk merumuskan hipotesis, berikut merupakan kerangka pemikiran teoritis dalam model penelitian pada gambar: 


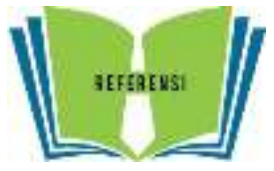

Gambar 1. Model kerangka pemikiran teoritis

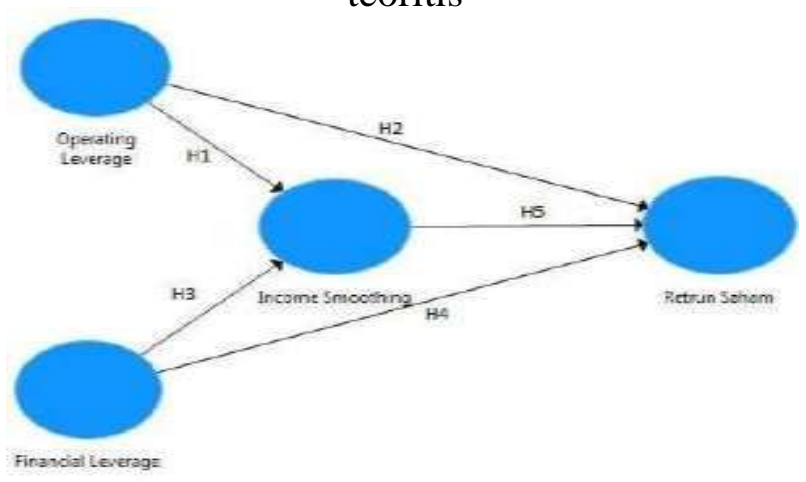

H-1 : Operating leverage berpegaruh signifikan terhadap income smooting.

Operating leverage timbul sebagai akibat dari adanya beban-beban tetap yang ditanggung dalam operasional perusahaan. Perusahaan yang memiliki biaya operasi tetap atau biaya modal tetap, maka perusahaan tersebut menggunakan leverage. Dengan menggunakan operating leverage perusahaan mengharapkan bahwa perubahan penjualan akan mengakibatkan perubahan laba sebelum bunga dan pajak yang lebih besar. (Hanafi, 2004).

Butar (2012) menyatakan bahwa operating leverage tidak mempengaruhi income smoothing. Cecelia (2012) menyatakan bahwa operating leverage tidak berpengaruh terhadap praktik income smoothing. Zuhroh (1993) Melakukan penelitian dan membuktikan membuktikan bahwa operating leverage memiliki pengaruh signifikan terhadap income smoothing.

$\mathbf{H}-\mathbf{2}$ : Operating leverage berpegaruh signifikan terhadap stock return

$$
\text { Medeiros et. al. }
$$
melakukan penelitian mengenai pengaruh operating leverage terhadap stock return (studi empiris di Brazil) dan hasilnya menyatakan bahawa terdapat hubungan positif antara operating leverage terhadap stock return. Sebaliknya, Ita (2009) menyatakan bahwa operating leverage tidak memiliki pengaruh singnifikan terhadap stock return.

H-3 : Financial leverage berpegaruh signifikan terhadap income smooting.

Christiana (2012) menyatakan bahwa Financial Leverage tidak berpengaruh terhadap income smoothing. Widana (2013) menyatakan bahwa financial leverage tidak berpengaruh terhadap tindakan income smoothing, sedangkan Xu Fengju (2013) menyatakan bahwa ada hubungan antara financial leverage dengan income smoothing. Penelitian ini juga menemukan bahwa kelompok perusahaan yang melakukan income smoothing dan kelompok perusahaan yang tidak melakukan income smoothing memiliki leverage dan profitabilitas yang berbeda.

H-4: Financial leverage berpegaruh signifikan terhadap stock return.

Hasil penelitian Ardiansyah (2004) menytakan bahwa financial leverage yang besar menandakan tingginya risiko kegagalan perusahaan untung mengembalikan utang-utangnya. Penelitian Sujoko (2007) mendukung teori yang disampikan oleh Weston \& Copelan (1997), bahwa dengan menggunakan ukuran leverage perusahaan yang besar menunjukkan perusahaan tersebut mengalami perkembangan, mengakibatkan investor merespon positif dan nilai perusahaan akan meningkat. Penelitian Pasaribu (2008) menjelaskan secara simultan dan parsial, pertumbuhan, profitabilitas, posisi leverage, likuiditas, dan efisiensi perusahaan berpengaruh terhadap harga saham di delapan industri.

H-5: Income smooting berpegaruh signifikan terhadap stock return.

Income smoothing merupakan praktik yang umum dilakukan oleh manajer perusahaan untuk mengurangi 


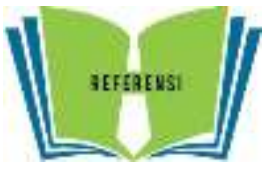

fluktuasi laba, yang diharapkan memiliki efek menguntungkan bagi evaluasi kinerja manajemen. Beberapa peneliti menemukan bahwa investor memiliki kecenderungan untuk berinvestasi di perusahaan yang menerapkan income smoothing. Investor percaya bahwa perusahaan yang memiliki laba dengan fluktuasi yang lebih halus memiliki tingkat pengembalian saham yang berbeda dan risiko investasi.

H-6: Operating leverage berpengaru tidak langsung terhadap stock retrun melalui Income smooting.

Penelitian ini juga akan menguji ada tidaknya pengaruh tidak langsung dari variabel operating leverage terhadap stock return melalui income smoothing sebagai variabel intervening. Pada pengujian melalui analisis jalur, akan terlihat variabel mana saja yang tidak signifikan, sehingga didapatkan persamaan yang memberikan pengaruh tidak langsung dari variabel operating leverage terhadap stock return melalui income smoothing.

H-7: Financial leverage berpengaru tidak langsung terhadap stock retrun melalui Income smooting.

Penelitian ini juga akan menguji ada tidaknya pengaruh tidak langsung dari variabel financial leverage terhadap stock return melalui income smoothing sebagai variabel intervening. Pada pengujian melalui analisis jalur, akan terlihat variabel mana saja yang tidak signifikan, sehingga didapatkan persamaan yang memberikan pengaruh tidak langsung dari variabel financial leverage terhadap stock return melalui income smoothing.

\section{METODE PENELITIAN}

Jenis penelitian yang digunakan dalam penelitian ini adalah explanatory research. Sumber data yang digunakan adalah data sekunder berupa laporan keuangan perusahaan yang tersedia online disitus http:/www.idx.co.id. Populasi dalam penelitian ini adalah semua perusahaan jasa sektor perbankan yang terdaftar di BEI. Sampel penelitian ini menggunakan metode purposive sampling sehingga hanya yang memenuhi syarat tertentu yang akan dijadikan sampel. Adapun syarat yang ditetapkan oleh peneliti adalah : (1) Perusahaan jasa sektor keuangan yang terdaftar di Bursa Efek Indonesia (BEI) yang menerbitkan dan mempublikasikan laporan keuangannya secara lengkap untuk laporan keuangan tahun 2010 sampai dengan 2015, ; (2) Perusahaan tidak mengalami kerugian selama periode penelitian serta menyediakan data yang dibutuhan dengan lengkap, sesuai dengan yang dibutuhkan dalam penelitian ini. Sehigga jumlah sampel yang digunakan dalam penelitian ini adalah 54 laporan keuangan dari 9 perusahaan jasa sektor perbankan.

Analisa data dalam penelitian ini menggunakan PLS (partial least square). Tujuan utama dari PLS adalah untuk menjelaskan hubungan antar konstruk dan menekankan tentang nilai hubungan tersebut. Hal penting yang harus diperhatikan dalam penggunaan PLS adalah keharusan adanya teori yang memberikan asumsi untuk menggambarkan model, pemilihan variabel, pendekatan analisis, dan interprestasi hasil. Untuk model yang kompleks dengan ukuran sampel yang relatif kecil antara 30-100 sampel (Ghazali, 2012).

Uji hipotesis dilakukan dengan melihat nilai path coeficient, yang menunjukan koefisien parameter dan nilai P-Value. Signifikasi parameter yang diestimasi memberikan informasi mengenai hubungan antara variabelvariabel penelitian kemudian membandingkan nilai P-Value dengan nilai signifikansi pada 5\%. Jika nilai PValue lebih kecil dari nilai signifikansi 
pada 5\%, maka hipotesa diterima. Jika nilai P-Value lebih besar atau sama nilai signifikansi pada 5\%, maka hipotesa ditolak.

Varibel yang digunakan dalam penelitian ini tidak hanya variabel

\section{Pengujian Pengaruh Langsung \\ Operating Leverage Terhadap Income \\ Smoothing}

Tabel 1. Hasil Pengujian Hipotesis

\begin{tabular}{|l|c|c|c|c|c|}
\hline Hubungan & $\begin{array}{l}\text { Original Sample Standard } \\
\text { Estimate }\end{array}$ & $\begin{array}{l}\text { T-Statistic } \\
\text { Deviation }\end{array}$ & P Value & $\begin{array}{l}\text { Standard } \\
\text { Eror }\end{array}$ \\
\hline $\begin{array}{l}\text { Operating } \\
\text { Leverage } \\
\rightarrow \text { Income Smooting }\end{array}$ & $-0,106$ & 0,057 & 0,024 & 0,981 & 0,261 \\
\hline
\end{tabular}

eksogen dan endogen tetapi juga terdapat variabel mediasi, yaitu variabel yang ikut mempengaruhi hubungan antara variabel prediktor (eksogen) dan kriterion (endogen). Pengujian hipotesis variabel mediasi dapat dilakukan melalui prosedur yang dikembangkan Sobel (Ghozali,2009), yang dikenal dengan uji sobel (Sobel test).

\section{HASIL PENELITIAN DAN PEMBAHASAN}

Pengujian hipotesis dengan menguji signifikansi koefisien jalur dari Partial Least Square (PLS), koefisien jalur menunjukkan besarnya pengaruh dari satu variabel eksogen terhadap variabel endogennya. Apabila nilai koefisien jalur signifikan maka dapat dinyatakan bahwa variabel eksogen tersebut berpengaruh signifikan terhadap variabel endogennya.

Gambar 2. Koefisien Jalur Hasil Analisis Partial Least Square (PLS)
Operating Leverage Terhadap Income Smooting

Sumber: data sekunder, diolah tahun 2016

Dari tabel 1 dapat dilihat hasil uji pengaruh operating leverage terhadap income smoothing memiliki hubungan yang negatif dengan koefisien parameter $(-0,106)$. Sedangkan operating leverage $\left(\mathrm{X}_{1}\right)$ tidak berpengaruh signifikan terhadap income smoothing $\left(\mathrm{Y}_{1}\right)$ karena memiliki nilai $\mathrm{P}$ Value $(0,981)$ lebih besar dari nilai toleransi kesalahan (alpha) sebesar 5\%. Sehingga dapat disimpulkan bahwa tidak ada hubungan dan pengaruh yang bermakna antara operating leverage $\left(\mathrm{X}_{1}\right)$ dengan income smoothing $\left(\mathrm{Y}_{1}\right)$, maka Hipotesa 1 ditolak.

Berdasarkan hasil penelitian ini menemukan bahwa perusahaan jasa sektor perbankan yang terdaftar di BEI periode 2010- 2015 memiliki tingkat perubahan volume penjualan dan EBIT

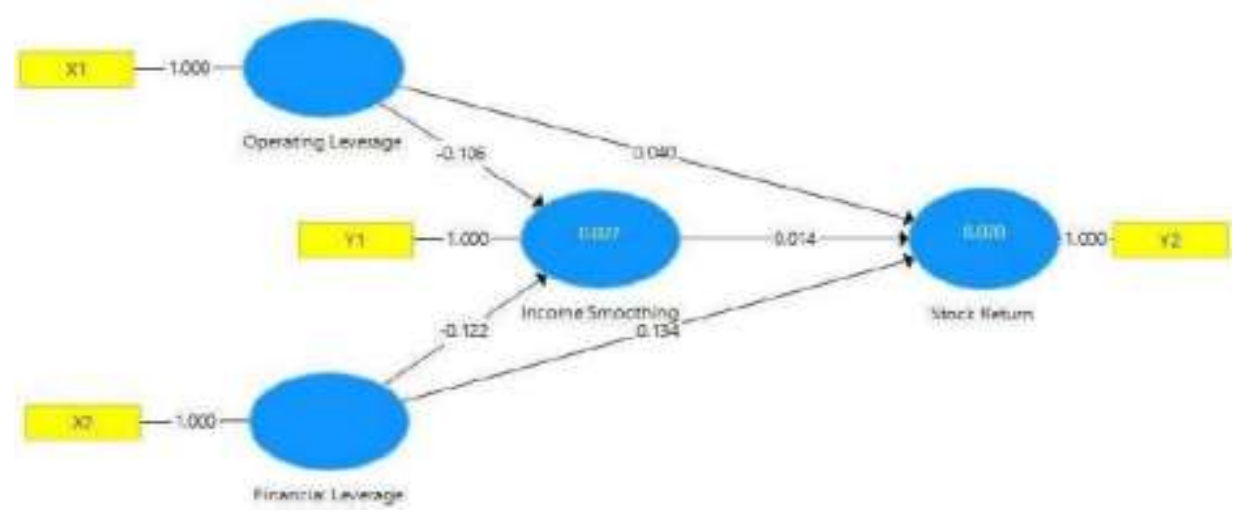


yang berbeda setiap tahunnya. Demikian pula dengan income smoothing yang diukur dengan indek eckel, yakni perbandingan koefisian variasi penjualan dan laba. Sesuai dengan uraian di atas operating leverage tidak berpengaruh terhadap income smoothing. Hal ini menunjukkan bahwa operating leverage belum terlalu diperhatikan oleh para manajer ataupun para pembuat keputusan investasi, sehingga operting leverage belum menjadi tolak ukur dalam income smoothing.

Operating leverage menunjukkan seberapa besar kebutuhan dana persuahaan yang didanai dengan hutang. Perusahaan dengan operating leverage yang tinggi mempunyai resiko penelitian yang dilakukan oleh Butar (2012) menyatakan bahwa operating leverage tidak mempengaruhi income smoothing, serta Cecelia (2012) menyatakan bahwa operating leverage tidak berpengaruh terhadap praktik income smoothing. Namun berbeda dari penelitian yang dilakukan oleh Zuhroh (1993), penelitiannya membuktikan bahwa operating leverage memiliki pengaruh signifikan terhadap income smoothing.

\section{Pengujian Pengaruh Langsung Operating Leverage Terhadap Stock Return}

Tabel 2. Hasil Pengujian Hipotesis Operating Leverage Terhadap Stock return

\begin{tabular}{|c|l|l|l|l|l|}
\hline Hubungan & $\begin{array}{l}\text { Original } \\
\text { Sample } \\
\text { Estimate }\end{array}$ & $\begin{array}{l}\text { Standard } \\
\text { Deviation }\end{array}$ & T-Statistic & P Value & $\begin{array}{l}\text { Standard } \\
\text { Eror }\end{array}$ \\
\hline $\begin{array}{l}\text { Operating leverage } \\
\rightarrow \text { Stock return }\end{array}$ & 0,040 & 0,057 & 2,281 & 0,023 & 0,167 \\
\hline
\end{tabular}

kerugian yang besar. Sehingga mendorong pemilik perusahaan untuk meminta menejer melaporkan bahwa perusahaan telah mempunyai operating leverage yang menguntungkan dengan situasi perekonomian saat ini, dengan tuntutan pemilik seperti ini seringkali menuntut manajer untuk melakukan tindakan income smoothing, minimal untuk mengurangi resiko tersebut.

Hutang yang digunakan dapat meningkatkan nilai perusahaan, tetapi pada suatu titik tertentu yaitu pada struktur modal yang optimal, nilai perusahaan yang semakin menurun dengan semakin besarnya jumlah hutang dalam struktur modalnya. Hal ini disebabkan karena manfaat yang diperoleh pada penggunaan hutang menjadi lebih kecil dibandaingkan biaya yang timbul atas pengguanan hutang tersebut.

Hasil penelitian ini sejalan dengan penelitian sebelumnya, yakni
Sumber : Data sekunder, data diolah 2016

Dari tabel 2 dapat dilihat hasil uji pengaruh operating leverage terhadap stock return memiliki hubungan yang positif dengan koefisien parameter $(0,040)$. Sedangkan operating leverage $\left(\mathrm{X}_{1}\right)$ berpengaruh signifikan terhadap stock return $\left(\mathrm{Y}_{2}\right)$ karena memiliki nilai $\mathrm{P}$ Value $(0,023)$ lebih kecil dari nilai toleransi kesalahan (alpha) sebesar 5\%. Sehingga dapat disimpulkan bahwa semakin tinggi nilai operating leverage (X1) maka nilai dari stock return $\left(\mathrm{Y}_{2}\right)$ juga akan menikangkat, dan terdapat pengaruh dari operating leverage $\left(\mathrm{X}_{1}\right)$ terhadap stock return $\left(\mathrm{Y}_{2}\right)$. Dari penjelasan tersebut Maka dapat dinayatakan bahwa Hipotesa 2 diterima.

Hasil dari penelitian ini menyatakan bahwa ketika nilai DOL (degree of operating levarege) 
meningkat, nilai stock return juga meningkat karena kedua varibel ini memiliki hubungan lurus. Hal ini dapat diartikan bahwa para investor berminat dengan resiko yang tinggi karena akan mendatangkan return yang tinggi,

\section{Pengujian Pengaruh Langsung Financial Leverage Terhadap Income Smoothing}

Tabel 3. Hasil Pengujian Hipotesis Financial LeverageTerhadapIncome Smoothing

\begin{tabular}{|c|c|c|c|c|}
\hline Hubungan & \begin{tabular}{|l} 
Original \\
Estimate
\end{tabular} & $\begin{array}{r}\text { Sample Standard } \\
\text { Deviation }\end{array}$ & T-Statistic & \begin{tabular}{|c|c|} 
P Value Standard \\
Eror
\end{tabular} \\
\hline $\begin{array}{l}\text { Financial leverage } \rightarrow \\
\text { income smoothing }\end{array}$ & $-0,122$ & 0,057 & 2,562 & 0,011 \\
\hline
\end{tabular}

dengan perubahan penjualan yang dapat menutupi biaya tetap dan menghasilkan laba. Dengan demikian DOL (degree of operating levarege) dapat mempengaruhi tingkat laba dan harga saham, sehingga mempengaruhi tingkat stock return.

Peningkatan resiko dan return dapat disebabkan oleh penignkatan operating leverage. Apabila penjualan turun, maka akan mengakibatkan laba mengalami penurunan yang signifikan. Bahkan, apabila penurunan penjualan sangat tinggi maka penjualan tersebut tidak dapat memenuhi biaya tetap yang dikeluarkan perusahaan, akibatnya perusahaan akan mengalami kerugian. Sehingga dapat dikatakan bahwa fulktuasi penjualan mempunyai pengaruh yang besar terhadap laba perusahaan pada perusahaan dengan operating leverage yang tinggi.

Hasil penelitian tersebut sejalan dengan penelitian sebelumnya, yakni penelitian yang dilakukan oleh oleh Medeiros et, al, (2003) melakukan penelitian mengenai pengaruh operating leverage terhadap stock return (studi empiris di Brazil) dan hasilnya menyatakan bahawa terdapat hubungan positif antara operating leverage terhadap stock. Namun penelitian ini bertentangan dengan penelitian yang dilakukan return Ita (2009) menyatakan bahwa operating leverage tidak memiliki pengaruh singnifikan terhadap stock return.
Sumber : Data sekunder, data diolah 2016

Dari tabel 3 dapat dilihat hasil uji pengaruh financial leverage terhadap income smoothing memiliki hubungan yang negatif dengan koefisien parameter $(-0,122)$. Sedangakan financial leverage $\left(\mathrm{X}_{2}\right)$ berpengaruh signifikan terhadap income smoothing $\left(\mathrm{Y}_{1}\right)$ karena memiliki nilai $P$ Value $(0,011)$ lebih kecil dari nilai toleransi kesealahan (alpha) sebesar 5\%. Sehingga dapat disimpulkan bahwa terdapat hubungan dan pengaruh yang bermakna antara financial leverage $\left(\mathrm{X}_{2}\right)$ terhadap income smoothing $\left(\mathrm{Y}_{1}\right)$, maka Hipotesa 3 diterima.

Financial leverage menunjukkan proporsi penggunan hutang untuk membiaya investasi, semakin besar hutang perusahaan maka semakin besar pula financial leverage perusahaan.

Perusahaan umumnya untuk menggunakan pendanaan ekuitas maupun hutang guna membiayai operasionalnya, semakin tinggi hutang perusahaan, maka semakin tinggi pula risiko yang dimiliki perusahaan tersebut. Kreditor tidak akan memberikan dana tanpa adanya jaminan pengembalian dan jaminana keamana atas dana tersebut. Oleh karena itu, agar performan perusahaan terlihat baik dimata kreditor, perusahaan yang mengalami kendala dalam menggunakan alternatif akuntansi untuk peningkatan volume pendapatan, atau dapat dikatakan perusahaan yang mendekati default dengan perjanjian 
hutang sangat potensial melakukan income smoothing.

Financial leverage atau yang biasa dihitung menggunakan degree of financial leverage (DFL) merupakan persentase perubahan laba per lembar saham (EPS) yang diakibatkan adanya perubahan dalam laba operasi (EBIT). Sedangkan income smoothing diukur dari indek eckel yakni perbandingan terhadap income smoothing, Widana (2013) menyatakan bahwa financial leverage tidak berpengaruh terhadap tindakan income smoothing.

\section{Pengujian Pengaruh Langsung Financial Leverage Terhadap Stock Return}

Tabel 4. Hasil Pengujian Hipotesis Financial Leverage Terhadap Stock Return

\begin{tabular}{|l|c|c|l|l|l|}
\hline \multicolumn{1}{|c|}{ Hubungan } & $\begin{array}{l}\text { Original } \\
\text { Sample } \\
\text { Estimate }\end{array}$ & $\begin{array}{c}\text { Standard } \\
\text { Deviation }\end{array}$ & T-Statistic & P Value & $\begin{array}{l}\text { Standar } \\
\text { Eror }\end{array}$ \\
\hline $\begin{array}{l}\text { Financial leverage } \\
\rightarrow \text { Stock Return }\end{array}$ & 0,134 & 0,057 & 1,369 & 0,172 & 0,184 \\
\hline
\end{tabular}

koefisian variasi penjualan dan laba. Financial leverage mencerminkan seberapa besarnya beban tetap yang digunakan oleh perusahaan dalam memaksimalkan modal yang digunakan. Contoh beban tetap keuangan tersebut adalah dari pembayaran bunga untuk hutang yang digunakan oleh perusahaan. Karena itu pembicaraan financial leverage berkaitan dengan struktur modal perusahaan. Perusahan yang menggunakan beban tetap tinggi berarti menggunakan hutang yang tinggi sehingga perusahaan dikatakan mempunyai tingkat financial leverage yang tinggi. Financial Leverage juga diperkirakan berpengaruh terhadap income smoothing, karena semakin tinggi rasio leverage maka semakin tinggi resiko yang harus ditanggung oleh investor yang akan berinvestasi pada perusahaan, serta semakin tinggi pula kecenderungan manajer untuk mempraktikan income smoothing.

Hasil penelitian ini sejalan dengan penelitian sebelumnya, yakni penelitian yang dilakukan oleh $\mathrm{Xu}$ Fengju (2013) menyatakan bahwa ada hubungan antara financial leverage dengan income smoothing, sedangkan Christiana (2012) menyatakan bahwa Financial Leverage tidak berpengaruh
Sumber : Data sekunder, data diolah 2016

Dari tabel 4 dapat dilihat hasil uji pengaruh financial leverage terhadap stock return memiliki hubungan yang positif dengan koefisien parameter $(0,134)$, Sedangkan financial leverage (X2) tidak berpengaruh signifikan terhadap stock return $\left(\mathrm{Y}_{2}\right)$ karena memiliki nilai P Value $(0,172)$ lebih besar dari nilai toleransi kesalahan (alpha) sebesar 5\%, Sehingga dapat disimpulkan bahwa tidak ada hubungan dan pengaruh yang bermakna antara

financial leverage $\left(\mathrm{X}_{2}\right)$ terhadap stock return $\left(\mathrm{Y}_{2}\right)$, maka Hipotesa 4 ditolak.

Financial leverage yang dapat dihitung dengan degree of financial leverage (DFL) merupakan persentase earing per share (perubahan laba per lemar saham) yang diakibatkan adanya perubahan dalam earning before interst

and tax (laba operasi). Sedangkan Stcok return merupakan hasil yang diperoleh darisuatu investasi dari dana yang sudah diinvestasikan yang dapat dinikmati oleh investor. Secara teoritis, semakin tinggi DFL akan menyebabkan semakin tinggi pula risiko. Karena pada dasarnya financial leverage menunjukkan besarnya penggunaan hutang untuk membiayai investasi, 
semakin besar kewajiban perusahaan maka semakin besar pula financial leverage perusahaan dan semakin tinggi pula resiko yang ditanggung perusahaan.

Hasil penelitian ini sejalan dengan penelitian yang dilakukan oleh

\section{Pengujian Pengaruh Langsung Income Smoothing Terhadap Stock Return}

Tabel 5. Hasil Pengujian Hipotesis Income Smoothing Terhadap Stock Return

\begin{tabular}{|l|c|c|c|c|c|}
\hline Hubungan & $\begin{array}{l}\text { Original } \\
\text { Sample } \\
\text { Estimate }\end{array}$ & $\begin{array}{c}\text { Standard } \\
\text { Deviation }\end{array}$ & T-Statistic & P Value & $\begin{array}{c}\text { Standard } \\
\text { Eror }\end{array}$ \\
\hline $\begin{array}{l}\text { Income Smoothing } \rightarrow \\
\text { Stock Return }\end{array}$ & 0,014 & 0,057 & 1,386 & 0,166 & 0,182 \\
\hline
\end{tabular}

Yunina (2013) dan Shabri (2013) yang menyatakan bahwa financial leverage yang tidak berpengaruh terhadap stock return. Financial leverage tidak berpengaruh terhadap stock return menunjukkan indikasi semakin tinggi financial leverage yang dihasilkan perusahaan tidak mempengaruhi tinggi atau rendahnya stock return yang akan diterima oleh investor. Hasil penelitian Masrahati (2009) menunjukkan pula bahwa financial leverage yang diukur dengan debt equity ratio tidak berpengaruh terhadap stock return. Hal ini diperkirakan terjadi karena jumlah perusahaan yang menggunakan pendaan dari hutang cukup besar pada periode penelitian waktu itu. Berbeda dengan penilitan yang dilakukan oleh Hasanah (2008), Hasil penelitian Hasanah (2008) menunjukkan bahwa financial leverage berhubungan positif dengan stock return, hubungan tersebut didasarkan pada trade-off theory dimana bila nilai perusahaan dapat dimaksimumkan maka harga saham akan naik dan stock return yang akan diterima investor juga akan meningkat.
Sumber : Data sekunder, data diolah 2016

Dari tabel 5 dapat dilihat hasi uji pengaruh antara income smoothing terhadap stock return memiliki hubungan yang positif dengan koefisien parameter $(0,014)$, Sedangakan income smoothing $\left(\mathrm{Y}_{1}\right)$ tidak berpegaruh signifikan terhadap stock return $\left(\mathrm{Y}_{2}\right)$ karena memiliki nilai $\mathrm{P}$ Value lebih besar dari nilai toleransi kesalahan (alpha) sebesar 5\% yakni 0,166. Sehingga dapat disimpulkan bahwa tidak ada hubungan dan pengaruh yang bermakna antara income smoothing $\left(\mathrm{Y}_{1}\right)$ terhadap Hipotesa 5 ditolak. stock return $\left(\mathrm{Y}_{2}\right)$, maka

Informasi akuntansi bergunabagi investor untuk membantu meraka dalam mengestimasi nilai yang diharapkan dan risiko dari stock return. Adanya keinginan investor untuk melakukan analisis kesehatan suatu saham dikareakan adanya keinginan investor atau calon investor akan hasil atau imbalan dalam hal ini adalah tingkat pengembalian saham yang layak dari suatu investasi saham. Beberapa peneliti percaya bahwa investor memiliki lebih banyak kecenderungan untuk berinvestasi di perusahaan yang menerapkan income smoothing. Investor akan lebih mudah untuk memperdiksi tingkat pengembalian dan risiko pada perusahaan yang memiliki laba yang rata untuk masa yang akan datang. 


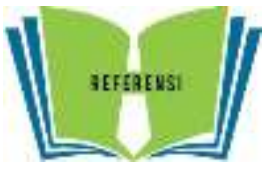

Hasil penelitian ini menyatakan bahwa income smoothing tidak berpengaruh terahadap stock return, hal ini berarti income smoothing pada perusahaan jasa sektor perbankan yang terdaftar di BEI periode 2010-2015 berkontribusi rendah terhadap stock return. Sehingga dapat dikatakan bahwa, fulktuasi laba dari tahun ke tahun tidak mempengaruhi tingkat pengembalian investasi atas modal yang ditanamkan oleh para investor. Hasil ini bertentangan dengan penelitian yang dilakukan oleh Asri (2013) yang menyatakan bahwa income smoothing berpengaruh signifikan positif terhadap stock return.

Pengujian Pengaruh Tidak Langsung Operating Leverage dan Financial Leverage Terhadap Stock Return Melalui Income Smoothing

Tabel 6. Model Struktural Hasil PLS: Pengaruh Tidak Langsung
$\left(\mathrm{Y}_{1}\right)$, diperoleh koefisien pengaruh tidak langsung sebesar -0,0014 dengan $P$ Value $(0,7283)$ lebih besar dari nilai $\alpha$ $(0,05)$ Sehingga dapat dinyatakan bahwa tidak terdapat pengaruh langsung antara operating leverage (X1) terhadap stock return $\left(\mathrm{Y}_{2}\right)$ melalui income smoothing $\left(\mathrm{Y}_{1}\right)$, maka Hipotesa 6 ditolak.

Varibel operating leverage diukur dengan menggunakan presentasi perubahan dalam laba operasi (EBIT) yang disebabkan perubahan satu persen dalam output (penjualan). Status income smoothing suatu perusahaan yang diklasifikasi dengan model Eckel. Perhitungan stock return yang dimaksud adalah total stock return dari investasi dalam suatu periode tertentu yang berhak diterima oleh investor.

Dalam beberapa penelitian disebutkan bahwa operating leverage merupakan salah satu faktor yang mempengaruhi income smoothing. Operating leverage juga mempengaruhi

\begin{tabular}{|c|c|c|c|c|c|c|}
\hline $\begin{array}{l}\text { Pengaruh } \\
\text { Tidak } \\
\text { Langsung }\end{array}$ & $\begin{array}{l}11 \\
\text { Koefi } \\
\text { Langs }\end{array}$ & Pengaruh & $\begin{array}{c}\text { Koefisien } \\
\text { Pengaruh } \\
\text { Tidak } \\
\text { Langsung }\end{array}$ & $\begin{array}{c}\text { t- } \\
\text { statistik } \\
\text { Dalam } \\
\text { Uji } \\
\text { Sobel }\end{array}$ & $\begin{array}{c}\text { P Value } \\
\text { Dalam } \\
\text { Uji } \\
\text { Sobel }\end{array}$ & $\begin{array}{l}\text { Standart } \\
\text { Eror } \\
\text { Dalam } \\
\text { Uji Sobel }\end{array}$ \\
\hline $\begin{array}{l}\text { Operating } \\
\text { Leverage } \rightarrow \\
\text { Income Smooting } \\
\longrightarrow \text { Stock Return }\end{array}$ & $\begin{array}{l}\text { Operating } \\
\text { Leverage } \\
\rightarrow \text { Income } \\
\text { Smooting } \\
=-0,106\end{array}$ & $\begin{array}{l}\text { Income } \\
\text { Smooting } \\
\rightarrow \text { Stock } \\
\text { Return = } \\
0,014\end{array}$ & $-0,0014$ & 0,3473 & $\begin{array}{c}0,728 \\
3\end{array}$ & 0,0372 \\
\hline $\begin{array}{l}\text { Financial Leverage } \\
\rightarrow \text { Income } \\
\text { Smooting } \rightarrow \\
\text { Stock Return }\end{array}$ & $\begin{array}{l}\text { Financial } \\
\text { Leverage } \\
\text { PIncome } \\
\text { Smooting } \\
=-0,122\end{array}$ & $\begin{array}{l}\text { Income } \\
\text { Smooting } \\
\rightarrow \text { Stock } \\
\text { Return }= \\
0,014\end{array}$ & $-0,0017$ & 0,2143 & $\begin{array}{c}0,830 \\
3\end{array}$ & 0,0603 \\
\hline
\end{tabular}

Sumber : Data sekunder, data diolah 2016

Pengaruh operating leverage terhadap stock return melalui income smoothing

Pengaruh tidak langsung antara operating leverage $\left(\mathrm{X}_{1}\right)$ terhadap stock return $\left(\mathrm{Y}_{2}\right)$ melalui income smoothing stock return seperti yang dinyatakan oleh Medeiros et, al, (2003), Sedangakan income smoothing juga mempengaruhi stock return.

Hasil penelitian ini menyatakan bahwa operating leverage tidak berpengaruh terhadap storck return melalui income smoothing. Hal ini dapat dikatakan bahwa perubahan volume 
penjualan dan laba operasi tidak mempengaruhi tingkat hasil pengembalian investasi saham, meskipun tidak terdapat perubahan fluktiasi laba dari tahun ke tahun.

\section{Pengaruh financial leverage terhadap stock return melalui income smoothing}

Pengaruh Pengaruh operating $\left(\mathrm{X}_{2}\right)$ terhadap stock return $\left(\mathrm{Y}_{2}\right)$ melalui income smoothing $\left(\mathrm{Y}_{1}\right)$, diperoleh koefisien pengaruh tidak langsung sebesar - 0,0017 dengan $\mathrm{P}$ Value $(0,8303)$ lebih besar dari nilai $\alpha(0,05)$, sehingga dinyatakan bahwa tidak terdapat pengaruh tidak langsung operating $\left(\mathrm{X}_{2}\right)$ terhadap stock return $\left(\mathrm{Y}_{2}\right)$ melalui income smoothing $\left(\mathrm{Y}_{1}\right)$, maka Hipotesa 7 ditolak.

Financial leverage yang biasa dihitung dengan degree of financial leverage (DFL) merupakan persentase perubahan laba per lembar saham (EPS) yang diakibatkan adanya perubahan dalam laba operasi (EBIT). Income smoothing diukur dari indek eckel yakni perbandingan koevisian variasi penjualan dan laba. Sedangkan Stcok return merupakan hasil yang diperoleh dari suatu investasi dari dana yang sudah diinvestasikanyang yang dapat dinikmati oleh investor.

Hasil penelitian ini menyatakan bahwa financial leverage tidak berpengaruh terhadap storck returnmelalui income smoothing. Hal ini dapat diartikan bahwa penggunaan sumber dana dari hutang yang menyebabkan perusahaan harus menanggung beban tetap finansial, tidak mempengarhui tingkat pengembalian hasil investasi yang diberikan perusahaan ke pada investor, meskipun tidak terdapat fluktuasi laba dari tahun ke tahun.

\section{KESIMPULAN DAN KETERBATASAN \\ Kesimpulan}

1. Hasil penelitian menyatakan bahwa operating leverage tidak berpengaruh terhadap income smoothing pada Perusahaan Jasa Sektor perbankan yang terdaftar di BEI periode 2010-2015. Sedangkan financial leverage berpengaruh terhadap income smoothing pada Perusahaan Jasa Sektor perbankan yang terdaftar di BEI periode 2010-2015.

2. Hasil penelitian menyatakan bahwa operating leverage berpengaruh terhadap stock return pada Perusahaan Jasa Sektor perbankan yang terdaftar di BEI periode 2010-2015. Hasil dari penelitian ini menyatakan bahwa ketiak nilai DOL meningkat, nilai stock return juga meningkat karena kedua varibel ini memiliki hubungan lurus serta tingkat operating levarege berpengaruh terhadap nilai stock retrun. Namun financila leverage tidak berpengaruh terhadap stock return pada Perusahaan Jasa Sektor perbankan yang terdaftar di BEI periode 2010-2015. Hal ini dapat dijelaskan karena jumlah pengembalian saham yang dibagiakan kepada investor tidak hanya tergantung pada nilai DOL dan DFL saja.

3. Hasil penelitian ini menyatakan bahwa income smoothing tidak berpengaruh terhadap stock return pada Perusahaan Jasa Sektor perbankan yang terdaftar di BEI periode 2010-2015.

4. Hasil penelitian ini menyatakan bahwa operating leverage dan financial leverage tidak berpengaruh terhadap storck retrun melalui income smoothing 


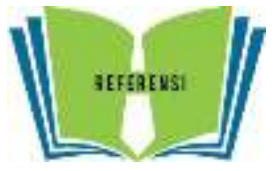

REFERENSI; Jurnal IImu Manajemen dan Akuntansi Volume 6, Nomor 2 (2018) pada Perusahaan Jasa Sektor perbankan yang terdaftar di BEI periode 2010-2015.

\section{Keterbatasan}

Penelitian ini memiliki beberapa keterbatasan yaitu sampel yang digunakan dalam penelitian ini tergantung pada kelengkapan data pada laporan keuangan dari perusahaan yang termasuk kedalam kelompok perusahaan jasa sektor perbankan tahun 2010-2015, sehingga tidak semua perusahaan yang dibutuhkan dapat dijadikan sampel karena adanya ketidakkelengkapan dari beberapa perusahaan yang tidak mempublikasikan laporan keuangannya sejak tahun 2010-2015.

\section{DAFTAR PUSTAKA}

Ardiansyah, M. 2004. "Pengaruh Variabel Keuangan terhadap Return Awal dan Return 5 Hari Setelah IPO serta Moderasi Besaran Perusahaan terhadap Hubungan Variabel Keuangan dengan Return Awal dan Return 5 Hari Setelah IPO di Bursa Efek Jakarta. Jurnal Riset Akuntansi Indonesia. 7(2) : 125-153.

Ashari, N., Koh H.C., Tan S.L., dan Wong W.H., 1994, "Factors Affecting Income Smoothing among Listed Companies in Singapore". Journal of Accounting and Business Research. Autumn. 291-304

Belkaouli, Ahmed. 1999. Accounting Theory. Illinois, USA : University of Illinois at Chicago.

Budiasih, I G A N. 2009. "Faktor-Faktor yang Mempengaruhi Praktik PerataanLaba". AUDI Jurnal Akuntansi dan Bisnis, 4 (1), Januari 2009, h:44-50.

Butar, Linda Kurniasih, dan Sri Sudarsi. Nopember 2012. "Pengaruh Ukuran Perusahaan, Profitabilitas, Leverage, dan
Kepemilikan Institusional terhadap Income smoothing: Studi Empiris pada Perusahaan Food and Beverages yang Terdaftar di BEI". Dinamika Akuntansi, Keuangan dan Perbankan,. Hal: 143 - 158 Vol. 1, No. 2. PP 143

Cecilia. Juli 2012. "Pengaruh Ukuran Perusahaan, Profitabilitas, dan Leverage Operasi terhadap Income smoothing pada Perusahaan Manufaktur di BEI. Jurnal Ilmiah Mahasiswa Akuntansi". Vol. 1. No. 4.

Christiana, Lusi. "Faktor-Faktor yang Mempengaruhi Praktek Income smoothing pada Perusahaan Manufaktur di BEI". Jurnal Ilmiah Mahasiswa Akuntansi". Vol. 1. No. 4.

Dwi Putra R.A. dan Wiwin Rahmanti.Maret 2013. Return dan Risiko Saham Pada Perusahaan Perata Laba dan Bukan Perata Laba. Jurnal Dinamika Akuntansi. Vol. 5, No. 1, , pp. 55-66

Ita Trisnawati. April 2009. "Pengaruh Economic Value Added, Arus Kas Operasi, Residual Income, Ernings, Financial Leverage dan Market Value Added terhadap Retrun Saham". Jurnal Bisnis dan Akuntansi. Vol. 11. No. 1. Hlm. 65-78.

Hanafi, M. M. dan A. Halim. 2004. Analisis Laporan Keuangan. Yogyakarta. Penerbit UPP AMP YKPN

Jogiyanto, Hartono. 2010. "Teori Portofolio dan Analisis Investasi". Yogyakarta: BPFE UGM."

Kementerian Keuangan Republik Indonesia. (2014). Modul Gambaran Umum

Martono, Agus Harjito. (2003). 


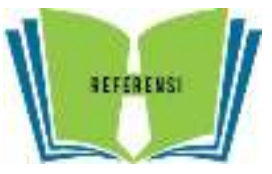

Manajemen keuangan.

Michelson, et. al. (2000). "The

Relationship between the

Smoothing of Reported Income and Risk Adjusted Returns".

Journal of Economics and

Finance, Vol.24 No.2, Summer 2000. Pp.141- 159

Okky Safitri, Sinarwati, Anantawikrama

Tungga Atmadja. (2015)

"Analisis Pengaruh

Profitabilitas, Likuiditas, Dan

Leverage Terhadap Return.

Pasaribu, R.B.F, 2008. "Pengaruh Varibel Fundamental terhadap

Harga Saham Persahaan Go Public di Bursa Efek Indonesia (BEI)". Jurnal Ekonomi dan Bisnis. 2(2).

Sartono, Agus . 2008 . "Manajemen Keuangan, Teori dan Aplikasi". Yogyakarta : BPFE.

Sujoko. 2007. "Pengaruh Struktur Kepemilikan Saham, Leverage, Faktor Internal dan External terhadap Nilai Perusahaan". Jurnal Manajemen dan Kewirausahaan. 9(1) : 41-48.

Syamsudin, Lukman . 2001. Manajemen Keuangan Perusahaan. Jakarta: PT Raja Grafindo Persada.

Weston, J.F. \& Copeland, T.E. 1997. "Manajemen Keuangan Jilid 2".

Edisi Kesembilan. Jakarta: Binarupa Aksara

$\mathrm{Xu}$ Fengju, Rasool Yari Fard, Leila Ghassab Maher, Nader Akhteghan. "The relationship between financial leverage and profitability with an emphasis on income smoothing in Iran's capital market". European Online Journal of Natural and Social Sciences 2013. vol.2. No. 3(s). pp. 156-164.

Yunina, F \& Shabri, M. 2013. “ Pengaruh Risiko Sistematik, Leverage, dan Laba terhadap
Retrun Saham pada Perusahaan Aneka Industri di Indonesia”. Jurnal Akuntansi, 2(12) : 56-64.

Zuhroh, D., "Faktor-faktor yang berpengaruh pada Tindakan Income smoothing pada Perusahaan Go Public di Indonesia". Tesis S2, Program Pasca Sarjana Universitas Gajah Mada. Yogyakarta. 1996.

Ghazali, I. (2013). Model persamaan struktural Konsep dan Aplikasi dengan Program AMOS 21.0 (Edisi ketujuh ed.).BP Undip. Semarang. 